\title{
Enteric Viral Infections among Domesticated South American Camelids: First Detection of Mammalian Orthoreovirus in Camelids
}

\author{
Dayana Castilla ${ }^{1}$, Victor Escobar ${ }^{1}$, Sergio Ynga $^{1}$, Luis Llanco ${ }^{2}{ }^{(0)}$, Alberto Manchego ${ }^{1}$, César Lázaro ${ }^{3}$, \\ Dennis Navarro ${ }^{4}\left(\mathbb{D}\right.$, Norma Santos ${ }^{5}$ (D) and Miguel Rojas ${ }^{1, *(\mathbb{C})}$
}

1 Laboratorio de Inmunología, Facultad de Medicina Veterinaria, Universidad Nacional Mayor de San Marcos, Lima, Apartado 03-5137, Peru; dayana.castilla@unmsm.edu.pe (D.C.); victor.escobar@unmsm.edu.pe (V.E.); sergio.ynga@unmsm.edu.pe (S.Y.); amanchegos@unmsm.edu.pe (A.M.)

2 Laboratorio de Zootecnia y Producción Agropecuaria, Facultad de Medicina Veterinaria, Universidad Nacional Mayor de San Marcos, Lima, Apartado 03-5137, Peru; 1llancoa@unmsm.edu.pe

3 Laboratorio de Farmacología y Toxicología Veterinaria, Facultad de Medicina Veterinaria, Universidad Nacional Mayor de San Marcos, Lima, Apartado 03-5137, Peru; clazarod@unmsm.edu.pe

4 Laboratorio de Virología, Facultad de Medicina Veterinaria, Universidad Nacional Mayor de San Marcos, Lima, Apartado 03-5137, Peru; dnavarrom@unmsm.edu.pe

5 Instituto de Microbiologia Paulo de Góes, Universidade Federal do Rio de Janeiro, Rio de Janeiro 21941-902, RJ, Brazil; nsantos@micro.ufrj.br

* Correspondence: mrojasm2@unmsm.edu.pe

\section{check for} updates

Citation: Castilla, D.; Escobar, V.; Ynga, S.; Llanco, L.; Manchego, A.; Lázaro, C.; Navarro, D.; Santos, N.; Rojas, M. Enteric Viral Infections among Domesticated South American Camelids: First Detection of Mammalian Orthoreovirus in Camelids. Animals 2021, 11, 1455. https://doi.org/10.3390/ani11051455

Academic Editors: Giulia Dowgier and Rosina Ehmann

Received: 15 April 2021

Accepted: 17 May 2021

Published: 19 May 2021

Publisher's Note: MDPI stays neutral with regard to jurisdictional claims in published maps and institutional affiliations.

Copyright: (c) 2021 by the authors. Licensee MDPI, Basel, Switzerland. This article is an open access article distributed under the terms and conditions of the Creative Commons Attribution (CC BY) license (https:// creativecommons.org/licenses/by/ $4.0 /)$.
Simple Summary: South American camelids (SACs) constitute the greatest livestock wealth of the Andean populations. Approximately half a million people from the high Andean areas are dedicated to the breeding of SACs as their main activity. In general, infectious diseases, particularly diarrheal infections, cause high morbidity and mortality in offspring and adult animals. In the study, we demonstrated that multiple virus pathogens circulate among neonatal SACs, and coinfections from other viruses might be common among SAC crias. We also demonstrated, for the first-time anywhere, the circulation of mammalian orthoreovirus in SACs or camelids. Diarrheal infections can potentially impact livestock productivity, which translates into serious economic losses for the Peruvian SAC industry, especially within rural communities, directly impacting their livelihood. Better knowledge of the infections that afflict these animals will enable the implementation of measures for the prevention and control of pathogens, the results of which will ultimately be reflected in improving the quality of life of these communities.

Abstract: Enteric infections are a major cause of neonatal death in South American camelids (SACs). The aim of this study was to determine the prevalence of enteric viral pathogens among alpacas and llamas in Canchis, Cuzco, located in the southern Peruvian highland. Fecal samples were obtained from 80 neonatal alpacas and llamas and tested for coronavirus (CoV), mammalian orthoreovirus (MRV), and rotavirus A (RVA) by RT-PCR. Of the 80 fecal samples analyzed, 76 (95\%) were positive for at least one of the viruses tested. Overall, the frequencies of positive samples were $94.1 \%$ and $100 \%$ among alpacas and llamas, respectively. Of the positive samples, 33 (43.4\%) were monoinfected, while $43(56.6 \%)$ had coinfections with two $(83.7 \%)$ or three $(16.3 \%)$ viruses. CoV was the most commonly detected virus (87.5\%) followed by MRV (50\%). RVA was detected only in coinfections. To our knowledge, this is the first description of MRV circulation in SACs or camelids anywhere. These data show that multiple viruses circulate widely among young alpaca and llama crias within the studied areas. These infections can potentially reduce livestock productivity, which translates into serious economic losses for rural communities, directly impacting their livelihoods.

Keywords: alpacas; llamas; Peru; rotavirus; coronavirus; mammalian orthoreovirus 


\section{Introduction}

South American camelids (SACs) constitute the greatest livestock wealth of Andean populations. The raising of alpacas and llamas is a crucial economic activity in Andean regions, enabling the production of fibers; primarily those of alpacas, which have a high value in international markets because of their fine texture. The llama, due to its size and physical strength, is also used as a pack animal and plays an important role in rural transportation. Peru possesses three million alpacas, the largest alpaca population in the world, and has a herd of approximately one million llamas. Most of these animals are found in the departments of the southern highlands, particularly in Puno and Cuzco. Over $80 \%$ of Peru's alpacas and the entire population of llamas are kept by small producers who lack adequate infrastructure for conducting both production and marketing activities of their products [1-3]. According to the Peruvian Ministry of Agrarian Development and Irrigation [1], Cuzco is the second most important center for alpaca and llama breeding in Peru, with the province of Canchis being the main producer. Unfortunately, neonatal mortality rates among alpacas and llamas in this province are $30 \%$ and $25 \%$, respectively [1] Diseases cause great losses due to both mortality and decreased productivity. Enteropathies are a major cause of neonatal death in SACs. The most significant pathogens causing diarrhea in SACs are Coccidia, Cryptosporidium spp., Giardia spp., Salmonella spp., Escherichia coli, Clostridium spp., rotavirus, and coronavirus [4-11].

Despite the vital importance of alpaca and llama breeding to the Peruvian economy, studies on enteric infections, particularly viral infections, in SACs are incipient. A better understanding of the epidemiology of enteric infections is essential to develop preventive measures. The aim of this study was to determine the prevalence of enteric viral pathogensspecifically coronavirus (CoV), mammalian orthoreovirus (MRV), and rotavirus A (RVA) associated with infections among alpacas and llamas in Canchis, Cuzco, located in the southern Peruvian highland.

$\mathrm{CoV}$ and RVA have already been identified as important diarrheal pathogens in neonatal SACs. On the other hand, MRV has not been associated to enteric infection. However, in a previous study, during the characterization of RVA strains detected in feces of alpacas and llamas collected in February 2014 in the province of Canchis in the state of Cusco, Peru, three viral strains containing 10 segments of double-stranded RNA (dsRNA) suggestive of MRV were isolated in an MA-104 cell culture [12]. In this study, we describe the characterization of these strains and investigate the prevalence of this virus in these animals.

\section{Materials and Methods}

\subsection{MRV Isolation and Characterization}

The protocol used for isolating MRV in cultures of African green monkey cells (MA-104) has been described elsewhere [12]. Viral culture supernatants were examined using polyacrylamide gel electrophoresis (PAGE) followed by silver nitrate staining [13]. Based on the PAGE profile suggestive of the MRV genome, specific primers were designed and used for amplification and sequencing of the MRV sigma 1 gene (Supplementary Table S1). The amplified genomic segments were sent for sequencing to Macrogen Inc. (Seoul, Korea). Overlapping sequences were assembled and edited using SeqMan, EditSeq, and MegAlign in the Lasergene software package (DNASTAR, Madison, WI, USA). Phylogenetic analysis was performed with MEGA software (version 7.0.14). Dendrograms were constructed using the maximum likelihood method based on the GTR-G model. Statistical significance was estimated by bootstrap analysis with 1000 pseudoreplicates. The sequences were compared to reference MRV strains obtained from GenBank (https: / / www.ncbi.nlm.nih.gov / nucleotide/, accessed on 5 April 2021). Sequences generated in this study were deposited in GenBank under the accession numbers MN200219, MN200220, and MN200221. 


\subsection{Fecal Samples}

Eighty fecal samples were collected from neonatal alpacas $(n=68)$ and llamas $(n=12)$, all one to five weeks old, with ( $n=43 ; 35$ alpacas and 8 llamas) and without ( $n=37$; 33 alpacas and 4 llamas) diarrhea, from three camelid breeding areas of the districts of Marangani (Silly and Quisini) and Sicuani (Pataccalasaya), province of Canchis, department of Cuzco, Peru. Samples were collected during the birthing season of alpacas and llamas, in January and February 2015. Fecal samples were collected directly from the rectum of animals and kept at $-20^{\circ} \mathrm{C}$ until processing at the Laboratory of Veterinary Virology and Immunology, Universidad Nacional Mayor de San Marcos, Lima, Peru.

\subsection{Viral RNA Extraction}

The extraction of viral RNA samples required an initial clarification process. Fecal suspensions were prepared at $10-20 \%$ in PBS (pH 7.2) and then centrifuged at $2500 \times g$ for $5 \mathrm{~min}$. Supernatant was filtered using a $0.22 \mu \mathrm{M}$ diameter filter. Viral RNA was extracted from clarified fecal supernatants using TRIzol ${ }^{\mathrm{TM}}$ LS Reagent (Thermo Fisher Scientific, Waltham, MA, USA) according to the manufacturer's recommendations.

\subsection{Viral Detection and Identification}

Samples were submitted to RT-PCR and nested PCR using specific primers (Table 1). Reverse transcription polymerase chain reaction (RT-PCR) and nested PCR were performed using the GoScript ${ }^{\mathrm{TM}}$ reverse transcription system and GoTaq ${ }^{\circledR}$ Green Master Mix (Promega, Madison, WI, USA), respectively. The genomic RNAs were subject to one cycle of reverse transcription $\left(5 \mathrm{~min}\right.$ at $25^{\circ} \mathrm{C}$ followed by $45 \mathrm{~min}$ at $42^{\circ} \mathrm{C}$ ), and one step of $2 \mathrm{~min}$ at $95{ }^{\circ} \mathrm{C}$ followed the cycles of PCR.

For CoV testing, the primers Cor-FW and Cor-RV, which amplify a 251-bp fragment of the RNA-dependent RNA polymerase (RdRp) gene of any CoV, were used for the first round of PCR, according to the protocol described previously [14]. Five microliters of the amplicons produced in the first round of PCR were used for BetaCoV detection, using the primers Beta.CoV.F and Beta.CoV.R, to generate a 227-bp fragment of polymerase-encoding gene. The PCR conditions were as follows: $3 \mathrm{~min}$ at $95^{\circ} \mathrm{C}$; followed by 35 cycles of PCR, each consisting of $40 \mathrm{~s}$ at $94^{\circ} \mathrm{C}, 1 \mathrm{~min}$ at $57^{\circ} \mathrm{C}$, and $40 \mathrm{~s}$ at $72{ }^{\circ} \mathrm{C}$; and the final extension step for $10 \mathrm{~min}$ at $72{ }^{\circ} \mathrm{C}$. BetaCoV-positive samples were subsequently analyzed by nested PCR for the identification of the subgenus Embecovirus (formerly known as BetaCoV lineage A, BetaCoV 1, or bovine-like $\mathrm{CoV}$ (BCoV-like)), using the first-round PCR products and specific CV2U and CV2L primers [15] that amplify all Embecovirus strains except for HCoV-HKU1 (AY597011) and ChRCoV (KM349742), with a predicted product of $136 \mathrm{bp}$. The PCR conditions were the same as described above for BetaCoV.

MRV detection was performed by one round of RT-PCR using the primers MRV-FM and MRV-RM. The primers used for MRV RT-PCR detection target the conserved genomic segment that encodes the RdRp. Selection was carried out in silico by aligning all MRV genomes deposited on GenBank, representatives of all serotypes (MRV1-MRV4), with a predicted product of $181 \mathrm{bp}$. The specificity of the primers was tested by amplifying the cell-cultured MRV strains and confirming the results by sequencing analysis. Sequences generated from the RdRp 181-bp amplicons were also deposited in GenBank under the accession numbers MN200216, MN200217, and MN200218. The PCR conditions were as follows: 3 min at $95^{\circ} \mathrm{C}$; followed by 40 cycles of PCR, each consisting of $40 \mathrm{~s}$ at $94{ }^{\circ} \mathrm{C}, 1 \mathrm{~min}$ at $45^{\circ} \mathrm{C}$, and $1 \mathrm{~min}$ at $72{ }^{\circ} \mathrm{C}$; and the final extension step for $5 \mathrm{~min}$ at $72{ }^{\circ} \mathrm{C}$. 
Table 1. Primers used in the RT-PCR and nested PCR assay for CoV, MRV, and RVA detection ${ }^{\dagger}$.

\begin{tabular}{|c|c|c|c|c|c|c|c|}
\hline Virus & Gene & Assay & Primer* & Primer Sequence $5^{\prime} \rightarrow 3^{\prime}$ & Position & Product Size (bp) & Reference \\
\hline \multirow{2}{*}{ All CoV } & \multirow{2}{*}{$\operatorname{RpRd}^{+}$} & \multirow{2}{*}{ RT-PCR } & Cor-FW & ACWCARHTVAAYYTNAARTAYGC & $14,922-14,944$ & \multirow{2}{*}{251} & \multirow{2}{*}{ [14] } \\
\hline & & & Cor-RV & TCRCAYTTDGGRTARTCCCA & $15,153-15,172$ & & \\
\hline BetaCoV & RpRd & Nested PCR & Beta.CoV.R & TCACAYTTWGGRTARTCCCADCCCA & $15,148-15,172$ & 227 & This study \\
\hline \multirow{2}{*}{ Embecovirus } & \multirow{2}{*}{ RpRd } & \multirow{2}{*}{ Nested PCR } & CV2U.F & TACTATGACTGGCAGAATGTTTCA & $14,996-15,019$ & \multirow{2}{*}{136} & \multirow{2}{*}{ [15] } \\
\hline & & & CV2L.R & AACATCTTTAATAAGGCGRCGTAA & $15,108-15,131$ & & \\
\hline \multirow{2}{*}{ All MRV } & \multirow{2}{*}{$\operatorname{RpRd}$} & \multirow{2}{*}{ RT-PCR } & MRV-FM & CCNATATCNGGAATGCAGAA & $1943-1962$ & \multirow{2}{*}{181} & \multirow{2}{*}{ This study } \\
\hline & & & MRV-RM & TCCATCATCGTRCTATTRTTNGC & $2102-2124$ & & \\
\hline \multirow{2}{*}{ All RVA } & \multirow{2}{*}{ NSP5 } & \multirow{2}{*}{ RT-PCR } & Gen_NSP5F & GGCTTTTAAAGCGCTACAG & $1-19$ & \multirow{2}{*}{667} & \multirow{2}{*}{ [16] } \\
\hline & & & Gen_NSP5R & GGTCACAAAACGGGAGT & $651-667$ & & \\
\hline \multirow{2}{*}{ All RVA } & \multirow{2}{*}{ NSP5 } & \multirow{2}{*}{ Nested PCR } & Max_1FM & CGTCAACTCTTTCTGGAAAATCTA & $95-121$ & \multirow{2}{*}{562} & \multirow{2}{*}{ [12] } \\
\hline & & & Max_4RM & GTGGGGAGCTCCCTAGT & $637-656$ & & \\
\hline
\end{tabular}

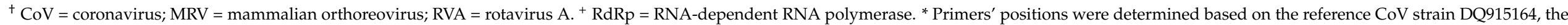
MRV strain M24734, and the RVA strain KT935485. 
RVA was detected using primers that amplify the NSP5-encoding gene, as described previously $[12,16]$.

All primers were synthesized by IDT (Integrated DNA Technologies, Coralville, IA, USA). Reactions were performed in a Bio-Rad T100 PCR thermal cycler (Bio-Rad Laboratories, Hercules, CA, USA). The PCR products were separated by $1.5 \%(w / v)$ agarose gel electrophoresis, stained with ethidium bromide, and visualized under UV light. A 100-bp DNA ladder (Promega, Madison, WI, USA) was used to determine molecular size.

To validate the PCR assays, positive controls were used for each of the studied viruses, which consisted of viral strains isolated in cell culture whose identification was previously confirmed by sequencing analysis. Strains AlpCoV-SA44 and AlpCoVHN (GenBank accession numbers KX266949 and KX266944, respectively), both Beta$\mathrm{CoV}$, subgenus Embecovirus, were used as CoV-positive controls. For MRV, strains SA44Alpaca, H8-Alpaca, and SL7-Llama (GenBank accession numbers MN200216, MN200217, and MN200218, respectively), identified as MRV-1, were used. RV strains RVA/Alpacatc/Per/ SA44/2014/G3P(30) (GenBank accession number KT935485) and RVA/Humanwt/Per/FRNM/2014/G3P(8)(14)(40)(50) (GenBank accession number KY972105), belonging to rotavirus species A (RVA), were used as positive controls.

\section{Results}

\subsection{MRV Characterization by PAGE and Sequencing}

Analysis of the migration profile of the dsRNA genome of three viral strains (SA44, H8, and SL7) isolated in MA-104 cells revealed an electrophoretic migration profile compatible with MRV (Figure 1). A sequence of $1069 \mathrm{bp}$ of the viral attachment protein sigma 1encoding gene was obtained for the alpaca (SA44 and H8) and llama (SL7) strains. They showed a nucleotide identity of $96.7 \%$ to $99.3 \%$ with bat strains, $96.7 \%$ to $96.9 \%$ with human strains, and $96.5 \%$ with mink MRV strains. Phylogenetic analysis identified those strains as serotype 1 (MRV1) (Figure 2).

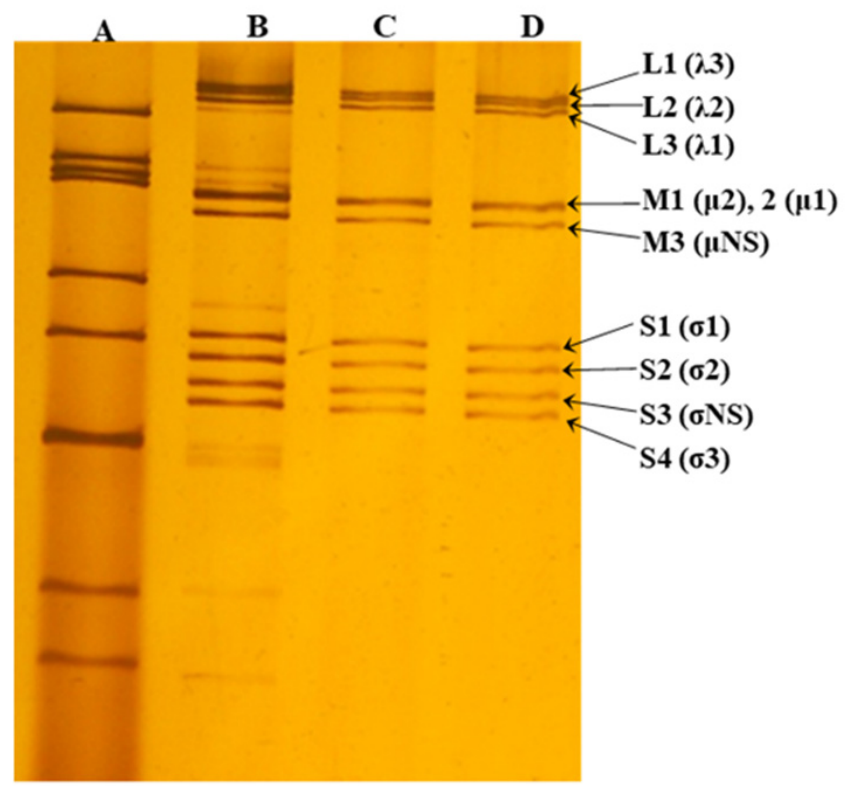

Figure 1. Polyacrylamide gel electrophoresis (PAGE) analysis of MRV dsRNA. PAGE of three strains isolated from intestinal contents of two alpacas (SA44 and H8) and one llama (SL7) in MA-104 cell line showing the 10 characteristic genomic segments of MRV: (A) SA-11 RVA strain exhibiting the typical 4-2-3-2 pattern (11 segments of dsRNA); (B) SA44 strain isolated showing a coinfection of RVA (11 genomic segments) and MRV (10 genomic segments); (C and D) strains H8 and SL7 exhibiting MRV monoinfection, showing the 10 dsRNA segments characteristic of MRV. Each segment of dsRNA is classified by size: genes L1-L3 (large segments), M1-M3 (medium segments) and S1-S4 (short segments) encode the proteins $\lambda 3-\lambda 1, \mu 2-\mu \mathrm{NS}$, and $\sigma 1-\sigma 3$, respectively. 


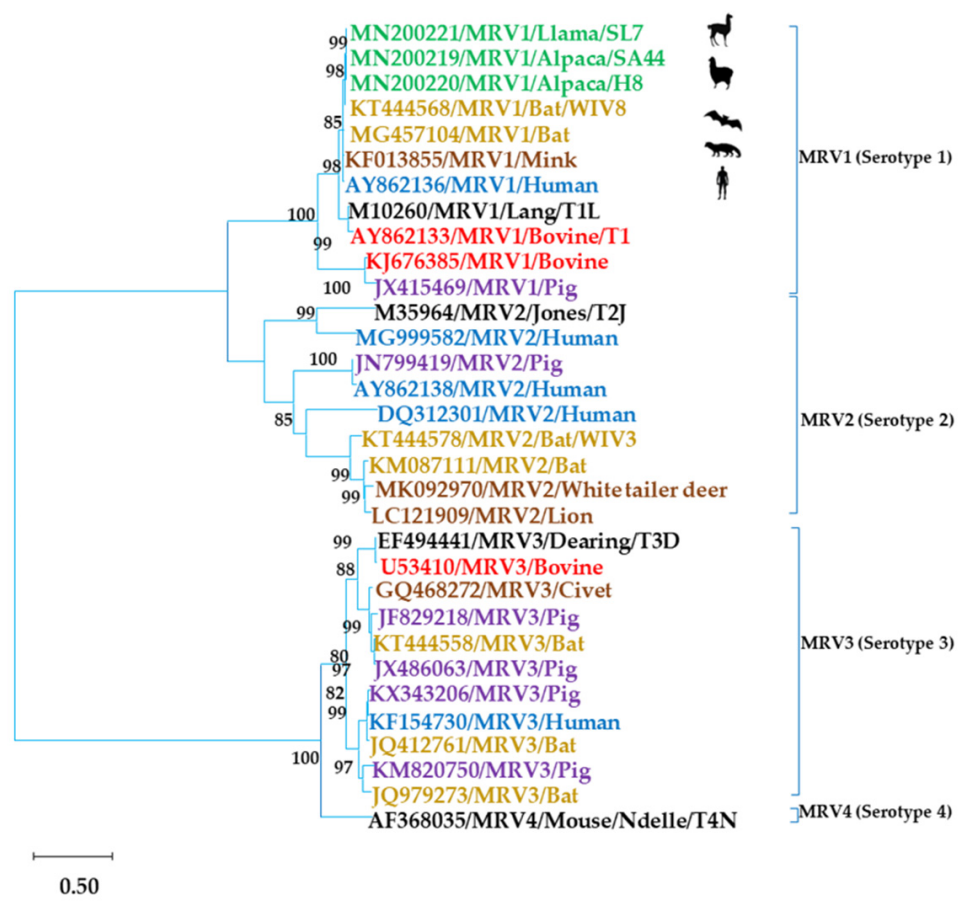

Figure 2. Phylogenetic trees constructed from partial nucleotide sequences (1069 bp) of the sigma 1 gene from MRV strains. Distances were corrected with the GTR-G model. Phylogenetic trees were constructed using the maximum likelihood method. Statistical support was provided by bootstrapping 1000 pseudoreplicates. Bootstrap values $>75 \%$ are given at branch nodes. The distance scale reflects substitutions/site. Reference samples are identified by GenBank accession numbers. In black, reference strains for each serotype.

\subsection{Virus Detection}

Of the 80 fecal samples, 76 (95\%) were positive for at least one of the screened viruses. Overall, the frequencies of positive samples were $94.1 \%$ and $100 \%$ among alpacas and llamas, respectively (Table 2). Positive samples were detected in all three sites of collection. Viral infections were observed among both symptomatic and asymptomatic animals, with no statistically significant difference $(p=0.1048)$. Specifically, among the 68 samples from alpacas, 26 were from animals with diarrhea and all tested positive. Of the 42 samples from alpacas without diarrhea, 38 tested positive. Among the 12 samples from llamas, 9 and 3 were from animals with and without diarrhea, respectively, and all tested positive.

Of the positive samples, 33 (43.4\%) were monoinfected, while $43(56.6 \%)$ had coinfections of two or three viruses (Table 2). The community with the highest rate of coinfections was Silly, at $69.7 \%$ (23/33) among alpacas and 41.7\% (5/12) among llamas, followed by Quisini and Pataccalasaya, at $47.8 \%(11 / 23)$ and $33.7 \%(4 / 12)$ among alpacas, respectively (Table 2). CoV was the most commonly detected virus in all studied communities, being present in $95.3 \%(n=29)$ of monoinfections and $95.3 \%(n=41)$ of coinfections. MRV was found in $12.1 \%(n=4)$ of monoinfections and $83.7 \%(n=36)$ of coinfections. RVA was only found in coinfections $(37.7 \% ; n=16)$ (Table 2$)$. 
Table 2. Distribution of viral infections among alpacas and llamas in three rural communities of the province of Canchis, Peru.

\begin{tabular}{|c|c|c|c|c|c|c|c|c|}
\hline \multirow{2}{*}{ Community/District } & \multirow{2}{*}{ Geographic Coordinates } & \multirow{2}{*}{ Host Species } & \multirow{2}{*}{$\mathbf{N}^{\circ}$ Tested Samples } & \multicolumn{5}{|c|}{$\mathrm{N}^{\mathrm{o}}$ of Positive Samples (\%) } \\
\hline & & & & $\mathrm{CoV}$ & MRV & RVA & Coinfections $^{+}$ & Total \\
\hline Silly/Marangani & $\begin{array}{c}14^{\circ} 21^{\prime} 12^{\prime \prime} \mathrm{S}, 71^{\circ} 10^{\prime} 17^{\prime \prime} \mathrm{W} \\
3800 \mathrm{masl}^{ \pm}\end{array}$ & Alpaca & 33 & 7 & 2 & 0 & $\begin{array}{c}23 \text { (16 CoV + MRV; } 3 \mathrm{CoV}+\mathrm{RVA} \\
1 \mathrm{MRV}+\mathrm{RVA} ; 3 \mathrm{CoV}+\mathrm{MRV}+\mathrm{RVA})\end{array}$ & $32(97)$ \\
\hline Quisini/Marangani & $\begin{array}{c}14^{\circ} 39^{\prime} 72^{\prime \prime} \mathrm{S}, 71^{\circ} 10^{\prime} 89^{\prime \prime} \mathrm{W} \\
4300 \mathrm{masl}\end{array}$ & Alpaca & 23 & 10 & 0 & 0 & $\begin{array}{c}11(4 \mathrm{CoV}+\mathrm{MRV} ; 3 \mathrm{CoV}+\mathrm{RVA} \\
4 \mathrm{CoV}+\mathrm{MRV}+\mathrm{RVA})\end{array}$ & $21(91.3)$ \\
\hline Pataccalasaya/Sicuani & $\begin{array}{c}14^{\circ} 16^{\prime} 9.5^{\prime \prime} \mathrm{S}, 71^{\circ} 9^{\prime} 39.1^{\prime \prime} \mathrm{W} \\
4700 \text { masl }\end{array}$ & Alpaca & 12 & 6 & 1 & 0 & $\begin{array}{c}4(2 \mathrm{CoV}+\mathrm{MRV} ; 1 \mathrm{CoV}+\mathrm{RVA} \\
1 \mathrm{MRV}+\mathrm{RVA})\end{array}$ & $11(91.7)$ \\
\hline Silly/Marangani & $\begin{array}{c}14^{\circ} 21^{\prime} 12^{\prime \prime} \mathrm{S}, 71^{\circ} 10^{\prime} 17^{\prime \prime} \mathrm{W}, 3800 \\
\text { masl }\end{array}$ & Llama & 12 & 6 & 1 & 0 & $5(\mathrm{CoV}+\mathrm{MRV})$ & $12(100)$ \\
\hline Total & & & 80 & 29 & 4 & 0 & 43 & $76(95)$ \\
\hline
\end{tabular}

$\mathrm{CoV}=$ coronavirus; $\mathrm{MRV}=$ mammalian orthoreovirus; $\mathrm{RVA}=$ rotavirus species $A .{ }^{\dagger}$ Coinfection with two or three viruses. ${ }^{ \pm}$meter above sea level. 


\subsection{Identification of CoV Genus and Subgenus}

Of the 70 samples positive for $\mathrm{CoV}, 66(94.3 \%)$ were identified as BetaCoV. Of these, $16(22.9 \%)$ belonged to the subgenus Embecovirus, with the majority of these samples (15/16) obtained from alpacas. The genus was not identified for 4 (5.7\%) and $71.4 \%$ of $\mathrm{CoV}$ and BetaCoV samples, respectively (Table 3).

Table 3. Identification of genus Betacoronavirus and subgenus Embecovirus in alpacas and llamas.

\begin{tabular}{ccccc}
\hline \multirow{2}{*}{ Host Species } & \multirow{2}{*}{$\mathbf{N}^{\mathbf{0}}$ of Samples } & \multicolumn{3}{c}{ Genus/Subgenus } \\
\cline { 3 - 5 } & & BetaCoV/EmbeCoV & BetaCoV/ Not Identified & Genus/Subgenus Not Identified \\
\hline Alpacas & 59 & 15 & 40 & 4 \\
Llamas & 11 & 1 & 10 & 0 \\
Total & 70 & $16(22.9 \%)$ & $50(71.4 \%)$ & $4(5.7 \%)$ \\
\hline
\end{tabular}

BetaCoV = genus Betacoronavirus; EmbeCoV = subgenus Embecovirus.

\section{Discussion}

There are few reports on enteric viral infections in SACs, particularly in Peru $[6,8-10,17,18]$. The majority of published studies were conducted in research centers with semi-intensive production systems with good nutritional and health management. Our study focused on small producers in rural communities with extensive production systems and inadequate health management training, who are responsible for more than $80 \%$ of the SAC herd in Peru.

In Peru, the SAC breeding area is geographically located over $3800 \mathrm{~m}$ above sea level. This presents an extreme climate and poor forage for animal species that are not typical of the Andean plateau, although it is possible to observe the rare presence of traditional livestock (cattle, sheep, horses, and pigs). An estimated one and a half million people from the high Andean areas were engaged in the breeding of SACs as their primary economic activity in the year 2000. However, the per capita income in these camelid-producing areas is the lowest in the country $[3,19,20]$.

The economic conditions of peasant communities such as those studied here, which are dedicated to the breeding of SACs, are chaotic due to extreme poverty. Their situation is becoming even more critical due to the lack of drinking water, vital hygienic services, and healthcare. These shortages are reflected in the health of their animals, which suffer greater disease burdens due to inadequate handling and lack of prophylactic programs. The animals are managed in extensive systems that use swampy areas watered by streams or rivers. Infectious and parasitic diseases are major limiting factors in the production of these animals. In general, infectious diseases cause high morbidity and mortality in both offspring and adult animals, which translate into serious economic losses for rural communities, directly impacting their livelihood $[4,6,21]$.

Our data showed a wide circulation of the surveyed viruses among alpacas and llamas in the three studied communities. $\mathrm{CoV}$ and RVA have already been identified as important diarrheal pathogens in neonatal SACs $[6,10,17,22]$. MRV, on the other hand, has been associated primarily with mild respiratory and enteric infections in mammals. Yet in the last decade, MRV has been associated with upper respiratory tract infections, encephalitis, and diarrhea [23-29]. In a previous study, we accidentally isolated three viral strains whose genome presented an electrophoretic profile similar to MRV [12]. The characterization of these isolates confirmed their identification as MRV1, with a high nucleotide identity with MRV1 strains from bats, humans, and mink (Figure 2). Therefore, we investigated the presence of MRV in new fecal samples of alpacas and llamas in an attempt to determine whether the detection of these strains was a rare event or whether this virus circulated frequently among these animals. In this study, MRV was the second most prevalent virus, detected in $50 \%$ of samples. In the Americas, this virus has been associated with diarrhea in calf and deer in the USA [24,27] and in humans in Brazil [30]. To our knowledge, this is the first description of MRV circulation in SACs or camelids anywhere. The high prevalence of 
infected animals suggests that this virus is well adapted to the environmental conditions of the Peruvian Andean highlands and local SAC herds.

Previous studies conducted in the Andean areas of the Peruvian highlands have shown the circulation of $\mathrm{CoV}$ in alpacas on farms with semi-intensive systems and in communities with extensive systems [6,8,22], with infection rates of $18.3 \%$ to $53.3 \%$. On the other hand, in alpacas reared under semi-intensive systems in research centers, $\mathrm{CoV}$ was detected in $26.8 \%$ of animals [17]. The variation in rates observed in different studies probably reflects differences in methodologies, the breeding system employed, and the sanitary conditions of each location. However, it is clear that this virus is widespread in Peruvian alpaca herds. Studies on CoV in llamas have not been reported in Peru. However, previous studies have disclosed $\mathrm{CoV}$ infections in outbreaks of diarrhea in llamas in the USA $[7,21]$. We observed a CoV infection rate of $91.7 \%$ among these animals.

Nucleotide sequences of alpaca $\mathrm{CoV}$ strains exhibited high identity with circulating bovine strains (EmbeCoV, formerly BetaCov 1), suggesting a possible bovine origin of these viruses $[10,16,30,31]$. The majority of $\mathrm{CoV}$ strains detected in alpacas $(72.7 \%)$ and llamas (90.1\%), although belonging to the Betacoronavirus genus, do not belong to the Embecovirus subgenus. These data suggest the circulation of different genera and subgenera of $\mathrm{CoV}$ among these animals.

RVA has already been associated with outbreaks of diarrhea among alpacas and llamas in the Peruvian highlands with high mortality rates $[6,9,22,32]$. Interestingly, in this study, RVA was only detected in coinfections. High rates of coinfections involving CoV and RVA have been described among SACs previously [6,22].

Virus-positive samples were detected among animals with and without diarrhea. The occurrence of asymptomatic infections in these animals could be due to the persistence of maternal immunity, or to the fact that as these pathogens are circulating widely in the herd, animals could have been infected before the study period and may have developed immunity, thus not presenting with diarrhea. Asymptomatic shedding is a source of contamination favoring the environmental persistence of these pathogens.

One of the most impressive findings of this study was the extremely high prevalence of coinfections $(56.6 \%)$. This can be explained by (i) the high sensitivity of the detection technique used in the study, (ii) the high circulation of these viruses among herds, and (iii) inadequate sanitary conditions for managing the animals, allowing the dissemination of pathogens. Unfortunately, we do not have information that allows us to infer the impact of coinfections on clinical presentations. However, it has been demonstrated that coinfections probably increase the severity of diarrhea in alpacas [6].

\section{Conclusions}

The raising of alpacas and llamas in Peru is conducted in a particular ecological niche by rural communities and is characterized by the close contact of shepherds with animals as well as failures in sanitary and prophylactic programs due to lack of economic resources. These factors facilitate interspecies transmission of viruses such as CoV, MRV, and RVA, triggering possible zoonotic or anthropozoonotic infections [32-34]. Consequently, epidemiological surveillance is essential to prevent and control the emergence or re-emergence of new viral genotypes and variants with zoonotic potential.

Supplementary Materials: The following are available online at https:/ / www.mdpi.com/article/10 .3390/ani11051455/s1, Table S1: Primers used for genotyping (serotype) of MRV1, MRV2, MRV3 and MRV4 of the controls isolated in the MA104 cell line.

Author Contributions: Conceptualization, M.R., A.M. and N.S.; methodology, D.C., V.E., S.Y., L.L., M.R., A.M. and D.N.; writing-original draft preparation, M.R., N.S. and C.L.; writing-review and editing, M.R., C.L., L.L. and N.S.; funding acquisition, M.R. All authors have read and agreed to the published version of the manuscript. 
Funding: This study was supported by CONCYTEC-FONDECYT en el marco de la convocatoria "Proyecto Investigación Básica 2019-01" (grant numbers 355-2019) and by the Vicerrectorado de Investigación y Posgrado de la Universidad Nacional Mayor de San Marcos en el marco de la convocatoria "Proyecto de Investigación con financiamiento para Grupos de Investigación 2021". This study was also partially supported by the Conselho Nacional de Desenvolvimento Científico e Tecnológico (CNPq grant numbers 404984/2018-5 and 301469/2018-0) and the Fundação Carlos Chagas de Amparo à Pesquisa do Estado do Rio de Janeiro, Brazil (FAPERJ, grant number E26/202.909/2017).

Institutional Review Board Statement: The procedures and techniques performed in alpacas and llamas used in the present study were approved by the Animal Research Ethics Committee of Facultad de Medicina Veterinaria, Universidad Nacional Mayor de San Marcos (FMV-UNMSM) and by Instituto Veterinario de Investigaciones Tropicales y de Altura (IVITA), protocol No. 2009-0001. Samples were taken following the animal handling protocol authorized by the Ethics and Animal Welfare Committee of FMV-UNMSM.

Data Availability Statement: The data presented in this study are available in Supplementary material and in GenBank database (https:/ / www.ncbi.nlm.nih.gov/genbank/, accessed on 5 April 2021) (accession numbers MN200216-MN200221).

Acknowledgments: We thank Miguel Angel Villareal Balboa for technical assistance and Elena Yudith Carrasco Charquero for being the administrative coordinator of "Proyecto Investigación Básica 2019-01" (grant numbers 355-2019).

Conflicts of Interest: The authors declare no conflict of interest. None of the authors of this paper have a financial or personal relationship with other people or organizations that could inappropriately influence the content of the paper. The funders had no role in the design of the study; in the collection, analyses, or interpretation of data; in the writing of the manuscript, or in the decision to publish the results.

\section{References}

1. Ministério de Agricultura y Riego, Perú (MINAG). 2021. Available online: http://www.minag.gob.pe/portal/sector-agrario/ pecuaria/situacion-de-las-actividades-de-crianza-y-produccion/cam\%C3\%A9lidos-sudamericanos (accessed on 31 March 2021).

2. Consejo Nacional de Camélidos Sudamericanos (CONACS). Estrategia Nacional de Desarrollo: Los Camélideos Domésticos em El Perú. 2005. Available online: https:/ / www.whyalpaca.com/assets/documentos/estrategia_nacional.pdf (accessed on 31 March 2021). (In Spanish).

3. Food and Agriculture Organization of the United Nations (FAO). Situación Actual de los Camelidos Sudamericanos en el Perú. 2005. Available online: https://tarwi.lamolina.edu.pe/ \{\}emellisho/zootecnia_archivos/situacion\%20alpcas\%20peru.pdf (accessed on 31 March 2021). (In Spanish).

4. Rosadio, A.R.; Maturrano, H.L.; Pérez, J.D.; Luna, E.L. El Complejo Entérico Neonatal en Alpacas Andinas. Rev. Investig. Vet. Perú 2012, 23, 261-271. [CrossRef]

5. Martín Espada, M.; Pinto Jiménez, C.; Cid Vázquez, M. Camélidos Sudamericanos: Estado Sanitario de Sus Crías. Rev. Complut. Cienc. Vet. 2010, 4, 37-50.

6. Rojas, M.; Manchego, A.; Rocha, C.B.; Fornells, L.A.; Silva, R.C.; Mendes, G.S.; Dias, H.G.; Sandoval, N.; Pezo, D.; Santos, N. Outbreak of Diarrhea among Preweaning Alpacas (Vicugna pacos) in the Southern Peruvian Highland. J. Infect. Dev. Ctries. 2016, 10, 269-274. [CrossRef] [PubMed]

7. Cebra, C.K.; Mattson, D.E.; Baker, R.J.; Sonn, R.J.; Dearing, P.L. Potential Pathogens in Feces from Unweaned Llamas and Alpacas with Diarrhea. J. Am. Vet. Med. Assoc. 2003, 223, 1806-1808. [CrossRef]

8. Garmendia, A.E.; Lopez, W.; Ortega, N.; Chamorro, M.J. Molecular Characterization of Rotavirus Isolated from Alpaca (Vicugna pacos) Crias with Diarrhea in the Andean Region of Cusco, Peru. Vet. Microbiol. 2015, 180, 109-112. [CrossRef] [PubMed]

9. Wellington López, P.; Marycris Chamorro, L.; Antonio, E.; Garmendia, B. Detección Rápida de Rotavirus y Coronavirus en Crías de Alpaca (Vicugna pacos) con Diarrea en la Región del Cusco, Perú. Rev. Investig. Vet. Perú. 2011, 22, $407-411$.

10. Luna, L.; Brandão, P.E.; Maturrano, L.; Rosadio, R.; Silva, F.D.F.; Soares, R.M.; Gregori, F. Betacoronavirus 1 in Alpacas (Vicugna pacos) in the High Peruvian Andes. Small Rumin. Res. 2015, 133, 7-9. [CrossRef] [PubMed]

11. Gomez-Puerta, L.A.; Gonzalez, A.E.; Vargas-Calla, A.; Lopez-Urbina, M.T.; Cama, V.; Xiao, L. Cryptosporidium parvum as a Risk Factor of Diarrhea Occurrence in Neonatal Alpacas in Peru. Parasitol. Res. 2020, 119, 243-248. [CrossRef]

12. Rojas, M.A.; Gonçalves, J.L.S.; Dias, H.G.; Manchego, A.; Santos, N. Identification of Two Novel Rotavirus A Genotypes, G35 and P[50], from Peruvian Alpaca Faeces. Infect. Genet. Evol. 2017, 55, 71-74. [CrossRef] [PubMed]

13. Herring, A.J.; Inglis, N.F.; Ojeh, C.K.; Snodgrass, D.R.; Menzies, J.D. Rapid diagnosis of rotavirus infection by direct detection of viral nucleic acid in silver-stained polyacrylamide gels. J. Clin. Microbiol. 1982, 16, 473-477. [CrossRef] 
14. Moës, E.; Vijgen, L.; Keyaerts, E.; Zlateva, K.; Li, S.; Maes, P.; Pyrc, K.; Berkhout, B.; van der Hoek, L.; van Ranst, M. A Novel Pancoronavirus RT-PCR Assay: Frequent Detection of Human Coronavirus NL63 in Children Hospitalized with Respiratory Tract Infections in Belgium. BMC Infect. Dis. 2005, 5, 6. [CrossRef]

15. Brandão, P.E. Coronavírus Bovino (BCoV): Ocorrência, Diversidade Molecular e Padronização de PCR para Diagnóstico a partir de Amostras Fecais de Bezerros com e sem Diarreia Criados em Municípios dos Estados de São Paulo e Minas Gerais, Brasil Ph.D. Thesis, Faculdade de Medicina Veterinária e Zootecnia, Universidade de São Paulo, São Paulo, Brazil, 4 April 2004.

16. Matthijnssens, J.; Ciarlet, M.; Rahman, M.; Attoui, H.; Bányai, K.; Estes, M.K.; Gentsch, J.R.; Iturriza-Gómara, M.; Kirkwood, C.D.; Martella, V.; et al. Recommendations for the Classification of Group A Rotaviruses Using All 11 Genomic RNA Segments. Arch. Virol. 2008, 153, 1621-1629. [CrossRef] [PubMed]

17. Rocha, C.B.; Fornells, L.A.A.M.G.; Rojas, M.; Libetal, M.; Manchego, A.; Pezo, D.; Santos, N. Molecular Epidemiology of Coronavirus in Faeces of Brazilian Calves and Peruvian Camelid Herds. J. Infect. Dev. Ctries. 2018, 12, 37-42. [CrossRef] [PubMed]

18. Siever Morales, C.; Daniel Paredes, L.; Danilo Pezo, C. Asociación de Rotavirus y Escherichia coli Fimbriada como Agentes Causales de Infecciones Entéricas en Alpacas Neonatas. Rev. Investig. Vet. Perú. 2007, 18, 150-153.

19. Quispe, E.; Rodríguez, T.; Iñiguez, L.; Mueller, J. Producción de Fibra de Alpaca, Llama, Vicuña y Guanaco en Sudamérica. Anim. Genet. Resour. Inf. 2009, 45, 1-14. [CrossRef]

20. Hermoza, L.G. Situacion y Perspectivas del Desarrollo del Sub Sector Camelidos Peruanos. 2011. Available online: https: / /1library.co/document/q5ovmr3z-situacion-perspectivas-desarrollo-sub-sector-camelidos-peruanos.html (accessed on 31 March 2021). (In Spanish).

21. Whitehead, C.E. Neonatal Diseases in Llamas and Alpacas. Vet. Clin. N. Am. Food Anim. Pract. 2009, 25, 367-384. [CrossRef] [PubMed]

22. Lucas, L.J.R.; Morales, C.S.; Barrios, A.M.; Rodríguez, G.J.; Vásquez, C.M.; Lira, M.B.; Torres, L.B.; Casas, A.E.; Espinoza, B.J. Patógenos Involucrados en Casos Fatales de Diarrea en Crías de Alpaca de la Sierra Central del Perú. Rev. Investig. Vet. Perú. 2016, 27, 169-175. [CrossRef]

23. Steyer, A.; Gutiérrez-Aguire, I.; Kolenc, M.; Koren, S.; Kutnjak, D.; Pokorn, M.; Poljšak-Prijatelj, M.; Rački, N.; Ravnikar, M.; Sagadin, M.; et al. High Similarity of Novel Orthoreovirus Detected in a Child Hospitalized with Acute Gastroenteritis to Mammalian Orthoreoviruses Found in Bats in Europe. J. Clin. Microbiol. 2013, 51, 3818-3825. [CrossRef] [PubMed]

24. Anbalagan, S.; Spaans, T.; Hause, B.M. Genome Sequence of the Novel Reassortant Mammalian Orthoreovirus Strain MRV00304/13, Isolated from a Calf with Diarrhea from the United States. Genome Announc. 2014, 2, e00451-14. [CrossRef]

25. Qin, P.; Li, H.; Wang, J.W.; Wang, B.; Xie, R.H.; Xu, H.; Zhao, L.-Y.; Li, L.; Pan, Y.; Song, Y.; et al. Genetic and Pathogenic Characterization of a Novel Reassortant Mammalian Orthoreovirus 3 (MRV3) from a Diarrheic Piglet and Seroepidemiological Survey of MRV3 in Diarrheic Pigs from East China. Vet. Microbiol. 2017, 208, 126-136. [CrossRef]

26. Li, Z.; Shao, Y.; Liu, C.; Liu, D.; Guo, D.; Qiu, Z.; Tian, J.; Zhang, X.; Liu, S.; Qu, L. Isolation and pathogenicity of the mammalian orthoreovirus MPC/04 from masked civet cats. Infect. Genet. Evol. 2015, 36, 55-61. [CrossRef]

27. Narayanappa, A.T.; Sooryanarain, H.; Deventhiran, J.; Cao, D.; Venkatachalam, B.A.; Kambiranda, D.; Kambiranda, D.; LeRoith, T.; Heffron, C.L.; Lindstrom, N.; et al. A Novel Pathogenic Mammalian Orthoreovirus from Diarrheic Pigs and Swine Blood Meal in the United States. MBio 2015, 6, e00593-15. [CrossRef]

28. Chua, K.B.; Voon, K.; Crameri, G.; Tan, H.S.; Rosli, J.; McEachern, J.A.; Suluraju, S.; Yu, M.; Wang, L.-F. Identification and Characterization of a New Orthoreovirus from Patients with Acute Respiratory Infections. Schwartz O, editor. PLoS ONE 2008, 3, e3803. [CrossRef]

29. Ahasan, M.S.; Subramaniam, K.; Sayler, K.A.; Loeb, J.C.; Popov, V.L.; Lednicky, J.A.; Wisely, S.M.; Krauer, J.M.C.; Waltzek, T.B. Molecular Characterization of a Novel Reassortment Mammalian Orthoreovirus Type 2 Isolated from a Florida White-Tailed Deer Fawn. Virus Res. 2019, 270, 197642. [CrossRef] [PubMed]

30. Rosa, U.A.; Ribeiro, G.O.; Villanova, F.; Luchs, A.; Milagres, F.A.P.; Komninaki, S.V.; Tahmasebi, R.; Lobato, M.C.A.B.S.; Brustulin, R.; Chagas, R.T.; et al. First identification of Mammalian Orthoreovirus Type 3 by Gut Virome Analysis in Diarrheic Child in Brazil. Sci. Rep. 2019, 9, 18599. [CrossRef] [PubMed]

31. Jin, L.; Cebra, C.K.; Baker, R.J.; Mattson, D.E.; Cohen, S.A.; Alvarado, D.E.; Rohrmann, G.F. Analysis of the Genome Sequence of an Alpaca Coronavirus. Virology 2007, 365, 198-203. [CrossRef] [PubMed]

32. Rojas, M.; Dias, H.G.; Gonçalves, J.L.S.; Manchego, A.; Rosadio, R.; Pezo, D.; Santos, N. Genetic Diversity and Zoonotic Potential of Rotavirus A Strains in the Southern Andean Highlands, Peru. Transbound. Emerg. Dis. 2019, 66, 1718-1726. [CrossRef]

33. Fung, T.S.; Liu, D.X. Human Coronavirus: Host-Pathogen Interaction. Annu. Rev. Microbiol. 2019, 73, 529-557. [CrossRef] [PubMed]

34. Dóró, R.; Farkas, S.L.; Martella, V.; Banyai, K. Zoonotic Transmission of Rotavirus: Surveillance and Control. Expert Rev. Anti Infect. Ther. 2015, 13, 1337-1350. [CrossRef] [PubMed] 